\title{
SENAM HAMIL UNTUK MENINGKATKAN DURASI TIDUR PADA IBU HAMIL TRIMESTER III
}

\author{
Hamdiah, Triyana Etty, Novi Indarwati \\ Program Studi Diploma III Kebidanan, Akademi Kebidanan Permata Husada Samarinda, 085387377632 \\ hamhamdian@gmail.com
}

\begin{abstract}
ABSTRAK
World Health Organization (WHO) memperkirakan setiap harinya 800 perempuan meninggal akibat komplikasi kehamilan dan proses melahirkan. Kematian maternal indikator penting dalam keberhasilan program kesehatan ibu sekaligus salah satu indikator dalam menggambarkan derajat kesehatan masyarakat. Senam hamil merupakan alternatif terapi latihan berupa aktivitas atau gerak yang diberikan pada ibu hamil untuk mempersiapkan diri, baik persiapan fisik maupun psikologis dalam kehamilan dan proses kelahiran. Tujuan penelitian ini adalah mengetahui pengaruh senam hamil terhadap durasi Tidur ibu hamil trimester III di Klinik Etam Tahun 2019. Jenis penelitian yang digunakan adalah Quasi Eksperimen desain penelitian non equivalent control group dengan jumlah sampel 20 Responden dengan analisis data menggunakan uji Wilcoxon. Hasil penelitian didapatkan bahwa nilai rata-rata durasi tidur pada kelompok intervensi 9,6 jam/hari dan pada kelompok control memiliki nilai rata-rata 6,4 jam/hari. Kelompok intervensi didapatkan nilai $p$ value 0,005 dan kelompok control 0,157. Ada perbedaan efektifitas senam hamil terhadap durasi tidur pada ibu hamil trimester III.
\end{abstract}

Kata kunci : durasi tidur; ibu hamil; senam hamil

\section{PREGNANCY EXERCISE TO IMPROVE SLEEP DURATION IN TRIMESTER III PREGNANT MOTHER}

\begin{abstract}
World Health Organization (WHO) estimates that every day, 800 women die due to pregnancy complications and childbirth. Maternal mortality is an important indicator in the success of maternal health programs as well as one indicator in describing the degree of public health. Pregnancy exercise is an alternative exercise therapy in the form of activities or movements given to pregnant women to prepare themselves, both physical and psychological preparation in pregnancy and birth process. The aim of this research was to identify effectiveness pregnant exercises towards sleep duration in pregnant mother trimester III in Etam Clinic in 2019. Type of research was quasi-experimental design with a non equivalent control group with 20 respondents. Data analysis used Wilcoxon test. The results showed that the average value of sleep duration after pregnancy exercise in the intervention group 9.6 and in the control group had an average value of 6.4. The wilcoxon test in the intervention group obtained $p$ value 0.005 and the control group 0.157 . This means that $H$ is rejected; there is a difference in the effectiveness of pregnancy exercises against sleep duration in third trimester pregnant women at the etam clinic in 2019.
\end{abstract}

Keyword: pregnancy exercise; sleep duration; pregnancy 


\section{LATAR BELAKANG}

World Health Organization (WHO) memperkirakan setiap harinya 800 perempuan meninggal akibat komplikasi kehamilan dan proses melahirkan . Laporan WHO tahun 2014 menunjukkan AKI di dunia sebesar 289.000 jiwa, Angka Kematian lbu di negara maju sebesar 16 per $100.000 \mathrm{KH}$, Kematian maternal merupakan masalah kesehatan global yang menjadi indikator penting dalam keberhasilan program kesehatan ibu sekaligus salah satu indikator dalam menggambarkan derajat kesehatan masyarakat (Kemenkes, 2015).

Kehamilan dapat berkembang menjadi masalah atau komplikasi setiap saat, setiap wanita hamil memiliki kemungkinan risiko yang berhubungan dengan keadaan kehamilannya hingga mengancam jiwa sehingga setiap wanita hamil memerlukan asuhan. Asuhan kehamilan menfasilitasi hasil yang sehat dan positif bagi ibu maupun janin, mendeteksi komplikasi, mempersiapkan persalinan serta memberikan Pendidikan (Khumaira, 2012). Adapun ketidaknyamanan yang sering terjadi pada ibu hamil trimester III adalah sering BAK, nyeri ligamentum, keputihan, sesak napas, nyeri pinggang dan gangguan tidur (Sulistyawati, 2009).

Gangguan tidur merupakan hal yang sering dialami wanita hamil.Walaupun kehamilannya normal, gangguan tidur pada wanita hamil bisa berupa penurunan persentase gelombang tidur yang lamban dan tidur REM yang mungkin meningkat pada stadium satu. Pada trimester tiga jumlah gangguan tidur ini lebih tinggi, karena adanya ketidaknyamanan seperti nyeri pinggang, banyak buang air kecil, dan spontan bangun dari tidur, gerakan janin, nyeri ulu hati, kram pada tungkai, kelelahan dan kesulitan memulai tidur sampai pagi (Grace et al. 2009).

National Sleep Foundation tahun 2007 menyatakan bahwa 97,3 \% wanita hamil trimester ketiga selalu terbangun dimalam hari dan rata - rata sekitar $78 \%$ wanita hamil di Amerika mengalami gangguan tidur. Menurut Reichner Tahun 2015 mengatakan bahwa gangguan pola tidur pada trimester pertama sebanyak $13 \%$, trimester kedua $19 \%$ dan meningkat di trimester akhir yaitu sebesar $66 \%$. Penurunan durasi tidur pada ibu hamil dapat membuat kondisi ibu hamil menurun, konsentrasi berkurang, mudah lelah, badan terasa pegal, tidak mood bekerja dan cenderung emosional. Hal ini dapat membuat beban kehamilan menjadi semakin berat. Gangguan tidur menimbulkan depresi dan stress yang berpengaruh pada janin yang dikandungnya. Stress ringan menyebabkan janin mengalami peningkatan denyut jantung tetapi stress yang berat dan lama akan membuat janin menjadi hiperaktif. Akibat lanjut dari gangguan tidur ini adalah depresi dan bayi yang dilahirkan memiliki sedikit waktu tidur yang dalam (Field et al. 2009).

Salah satu upaya untuk mengatasi kesulitan tidur ini antara lain dengan mengonsumsi obat-obatan yang aman bagi ibu hamil, hipnoterapi, edukasi tidur, Iatihan relaksasi dan olahraga (Hegard \& Hanke K, 2010). Senam hamil merupakan suatu metode yang penting untuk mempertahankan atau memperbaiki keseimbangan fisik terhadap calon ibu atau merupakan suatu usaha untuk mencapai kondisi yang optimal dalam mempersiapkan proses persalinan dengan cara dirancang latihan-latihan bagi ibu hamil (Maryunani \& Sukaryati, 2011).

Tujuan penelitian adalah mengetahui pengaruh senam hamil terhadap durasi tidur pada ibu hamil trimester III.

\section{METODE}

Penelitian ini dilakukan di Klinik Etam Jl. Jelawat kelurahan Sungai pinang. Jenis penelitian yang digunakan adalah eksperimen semu (quasi eksperimen) dengan desain non equivalent control group dengan desain penelitian pretest-postest. Populasi adalah semua ibu hamil trimester III yang berada di Klinik Etam. Jumlah sampel ibu hamil trimester III sejumlah 20orang dimana pada kelompok intervensi 10 orang dengan jumlah intervensi 4 kali selama 1 bulan dan pada kelompok control 10 orang yang tidak melakukan senam hamil. Teknik pengambilan sampel dalam penelitian ini adalah cluster random sampling. Analisis data bivariat 
menggunakan uji Wilcoxon karena data berdistribusi tidak normal.

HASIL

Setelah dilakukan uji normalitas dengan menggunakan uji Shapiro Wilk menunjukkan bahwa data post-test pada kelompok intervensi tidak normal.

Tabel 1. Distribusi frekuensi durasi tidur ibu hamil TM III sebelum senam hamil di Klinik Etam 2019 ( $n=10)$

\begin{tabular}{l|lccc}
\hline No & $\begin{array}{l}\text { Durasi } \\
\text { Tidur }\end{array}$ & Min & Max & Mean \\
\hline 1 & Intervensi & 4 & 8 & 5,9 \\
\hline 2 & Kontrol & 5 & 8 & 6,2 \\
\hline
\end{tabular}

Tabel 1 menunjukkan bahwa durasi tidur pada ibu hamil pada kelompok intervensi (yang tidak diberikan senam hamil) dengan nilai minimal 4 jam/hari dan nilai maximal 8 jam/hari didapatkan nilai rata-rata 5,9 jam/hari, dan pada kelompok kontrol dengan nilai minimal 5 jam/hari dan nilai maximal 8 jam/hari didapatkan nilai rata-rata 6,2 jam/hari.

Setelah dilakukan observasi durasi tidur maka diberikan tindakan senam hamil sebanyak 4 kali dalam seminggu dengan durasi 60 menit. Adapun hasil dari tindakan senam hamil pada kelompok intervensi sebagai berikut;

Tabel 2. Distribusi frekuensi durasi tidur ibu hamil TM III sesudah senam hamil di Klinik Etam 2019 ( $n=10)$

\begin{tabular}{lllll}
\hline No & $\begin{array}{l}\text { Durasi } \\
\text { Tidur }\end{array}$ & Min & Max & Mean \\
\hline 1 & Intervensi & 8 & 10 & 9.6 \\
\hline 2 & Kontrol & 5 & 8 & 6.4 \\
\hline
\end{tabular}

Tabel 2 menunjukkan bahwa durasi tidur pada ibu hamil setelah diberikan senam hamil pada kelompok intervensi dengan nilai minimal 8 jam/hari, nilai maximal 10 jam/hari dan nilai rata-rata 9,6 jam/hari. Pada kelompok kontrol dengan nilai minimal 5 jam/hari, nilai maksimal 8 jam/hari dan nilai rata-rata 6,4 jam/hari. Nilai rata-rata tersebut dapat diketahui gambaran durasi tidur yang signifikan antara kelompok intervensi dan kelompok kontrol setelah dilakukan senam hamil (tabel 3).

Tabel. 3 Perbedaan Durasi tidur ibu hamil sebelum dan sesudah senam hamil di Klinik Etam 2019 ( $n=10)$

\begin{tabular}{lllll}
\hline No & $\begin{array}{c}\text { Durasi } \\
\text { Tidur }\end{array}$ & $\mathbf{Z}$ & \multicolumn{1}{c}{$\boldsymbol{\Delta \text { Mean }}$} & P Value \\
\hline 1 & Intervensi & $-2,821$ & 3.7 & 0.005 \\
\hline 2 & Kontrol & -1.414 & 0.2 & 0.157 \\
\hline
\end{tabular}

Tabel 3 menunjukkan bahwa pada kelompok intervensi (yang diberikan senam hamil) terjadi peningkatan durasi tidur selama 3.7 jam/hari , sedangkan kelompok control (yang tidak diberikan senam hamil) terjadi peningkatan durasi tidur sebanyak 0.2 jam/hari). Hasil uji Wilcoxon pada kelompok intervensi didapatkan $p$-value $0,005<(\alpha 0,05)$, $\mathrm{Ha}$ diterima sehingga ada perbedaan durasi tidur ibu hamil Trimester III sebelum dan sesudah diberikan senam hamil. Sedangkan pada kelompok kontrol didapatkan $p$-value $0,157>(\alpha \quad 0,05)$, Ha ditolak sehingga tidak ada perbedaan durasi tidur.

\section{PEMBAHASAN}

Selama hamil tubuh Ibu butuh tidur selama 78 jam sehari Pada kehamilan trimester ketiga, ibu hamil merasakan ketidaknyamanan fisik yang sering kali mengganggu istirahat ibu. Secara psikologis pada trimester ketiga ini biasanya ibu mengalami rasa takut dan cemas menghadapi persalinan. (Sri Astuti, 2017).

Ketidaknyamanan fisik berhubungan dengan perubahan bentuk tubuh, ketidaknyamanan fisik ini seperti sakit punggung bawah, dan rasa pegal pada badan. Kecemasan dan ketidaknyamanan fisik merupakan stressor yang dapat merangsang sistem syaraf simpatis dan modula kelenjar adrenal. Pada keadaan ini akan terjadi peningkatan sekresi hormone adrenalin atau epinefrin, sehingga dapat meningkatkan ketegangan pada ibu hamil 
yang mengakibatkan ibu hamil menjadi lebih gelisah dan tidak mampu berkonsentrasi. Kondisi ini dapat menyebabkan kecemasan dan ketidaknyamanan fisik lebih lanjut sehingga ibu hamil lebih sulit untuk tidur

Buruknya kualitas tidur berhubungan dengan risiko depresi, sedikitnya waktu tidur dan buruknya kualitas berhubungan dengan kejadian diabetes mellitus dan obesitas. Selain itu, gangguan tidur dapat mempengaruhi sistem kardiovaskular, neuroendokrin, metabolisme, dan imunitas tubuh (Buysse, 2014).

Gangguan tidur seperti gangguan durasi dan kualitas tidur memiliki pengaruh terhadap respon inflamasi tubuh. Hormon-hormon seperti adrenal atau katekolamin serta aktivasi saraf simpatis meningkatkan sitokin proinflamasi dari sel-sel dan organ imun tubuh. Selain itu,katekolamin mengganggu tidur, hormon seperti kortisol juga memiliki pengaruh untuk terjadinya inflamasi. Kortisol dapat menurunkan produksi dari sitokin inflamasi. Hormon ini dilepaskan secara diurnal berdasarkan irama sirkadian. Namun pada gangguan tidur, hormon kortisol dilepaskan berlebihan dan kronis sehingga dapat menyebabkan negative feedback yang justru menurunkan sensitivitas reseptor hormon kortisol dan menurunkan efek dari hormon itu sendiri (Okun, 2009).

Michelle William pada hasil risetnya, menyatakan secara umum ibu hamil membutuhkan tidur 7-8 jam setiap hari, kurang dari waktu tersebut akan berdampak pada kesehatannya. pada ibu hamil yang tidur kurang dari 7 jam setiap malam sehingga dapat menyebabkan resiko pre-eklamsia lebih tinggi.

Senam hamil (prenatal) merupakan terapi latihan berupa aktivitas atau gerak yang diberikan pada ibu hamil untuk mempersiapkan diri, baik persiapan fisik maupun psikologis untuk menjaga keadaan ibu dan bayi tetap sehat (Widianti, 2009). Gerakan senam hamil berefek membuat relaksasi yang dapat menstabilkan kecemasan dan mengurangi rasa takut dengan cara relaksasi fisik dan mental, serta mendapatkan informasi yang mempersiapkan mereka untuk mengalami apa yang akan terjadi salama persalinan dan kelahiran, sehingga ibu hamil menjadi lebih relaks selama masa kehamilan yang membuat ibu hamil dapat tidur dan istirahat lebih nyaman sehingga meningkatkan kualitas dan durasi tidur pada ibu hamil (Wibowo \& Larasati, 2012).

Hal ini juga didukung penelitian oleh Wahyuni \& Ni'mah (2013) menyatakan bahwa senam hamil akan memberikan efek relaksasi pada ibu hamil yang bisa berpengaruh terhadap peningkatan durasi tidur bagi ibu hamil trimester III.

\section{KESIMPULAN DAN SARAN}

Ada peningkatan durasi tidur pada ibu hamil setelah melakukan senam hamil 4 kali dalam seminggu selama 60 menit. Saran bagi ibu hamil TM III untuk melakukan senam hamil untuk meningkatkan durasi tidur ibu selama hamil.

\section{REFERENSI}

Astuti, S. (2017). Asuhan ibu dalam masa kehamilan. Jakarta: Erlangga.

Buysse DJ, et al (2008). Relationships between the pittsburgh sleep quality index (psqi), epworth sleepiness scale (ess), and clinical polysomnographic measures in a community sample. Journal of Clinical Sleep Medicine. 4(6):563-71.

Field et al. (2006). Sleep Disturbansces in Depressed Pregnant Women and Their Newborns. Infant Behavior and Development.

Grace W. Pien, MD. Richard J \& Schwab, MD (2009). Sleep Disorder During Pregnancy. SLEEP, 27(7)

Hegard, Hanne \& Hanke. (2010). Experience of Physical Activity During Pregnancyin Danish Nulliparous Women with A Physically Active Life Before Pregnancy, A Qualitative Study. BMC Pregnancy and Childbirth

Kemenkes RI. (2015).Kesehatan dalam kerangka Suistainable Development Goals(SDG'S). Jakarta: Kementrian Kesehatan RI.

Khumaira, M. (2012). IImu Kebidanan.. Yogyakarta : Mitra Setia 
Okun, M.L., Schetter, C.D., \& Glynn, L.M. (2011). Poor sleep quality is associated with preterm birth. Sleep; 34:1493e8.

Sulistyawati,A. (2009). Asuhan kebidanan pada masa Kehamilan. Jakarta: Salemba Medika.

Maryuni, Anik dan Yetty Sukaryati. (2011). Senam Hamil, Senam Nifas dan terapi musik. Jakarta : Trans info media.

Wahyuni \& Ni'mah. (2013). Manfaat Senam Hamil Untuk Meningkatkan Durasi Tidur Ibu Hamil. Jurnal Kesehatan Masyarakat, 8(2), 113-120
Widianti, N. (2009). Efektivitas Senam Hamil Untuk Mengurangi Kecemasan Pada Ibu Hamil. Semarang: Universitas Katolik Soegijapranata

Wibowo \& Larasati, (2012). Pengaruh Keikutsertaan Senam Hamil Terhadap Kecemasan Primigravida Trimester Ketiga Dalam Menghadapi Persalinan. Jurnal Biometrika dan Kependudukan, Volume 1 Nomor 1, Agustus 2012 : 26-32 